\title{
Psychologiczne uwarunkowania aktów dehumanizacji
}

Zjawisko dehumanizacji, choć rozumiane obecnie rozmaicie, z pewnością nie może być zawężane do aktów fizycznego poniżania, maltretowania czy odbierania poczucia człowieczeństwa w sposób fizyczny. Dehumanizacja występuje bowiem o wiele częściej w postaci dość subtelnych form psychologicznego oddziaływania na innych, które w efekcie czynią podmiot społeczny nieludzkim, pozbawionym subiektywnego poczucia bycia pełnowartościowym uczestnikiem życia społecznego, co bardzo wyraźnie widać chociażby na przykładzie negatywnej stereotypizacji. I choć zdecydowanie rzadziej jest ona przedmiotem zainteresowania rządzących czy politologów lub prawników, bardzo często stanowi wstęp do fizycznych aktów dehumanizacji, a następnie przemocy, w sprzyjających zaś warunkach - eksterminacji jednostek lub całych grup społecznych ${ }^{1}$.

Wyjaśnianie aktów dehumanizacji na gruncie wiedzy psychologicznej przez wiele lat było mocno uzależnione od dość naturalnej perspektywy, jaką przyjmowali komentatorzy historii i badacze źródeł, mianowicie od obligatoryjnej, a zarazem banalnej konstatacji, że każdy czyn jest przez kogoś dokonywany. W związku $\mathrm{z}$ tym zupełnie naturalne wydawało się skupienie uwagi na podmiocie dopuszczającym się określonych czynów. Podejmowano obszerne badania, których centrum stanowił działający podmiot i jego świat wewnętrzny. Umysł i emocje człowieka stały się kluczową zmienną mającą wyjaśnić naturę, a przede wszystkim źródła

* Dziękuję recenzentom za wnikliwą lekturę i cenne uwagi, które znacząco podniosły merytoryczną zawartość tekstu.

1 ,Theorists of dehumanization have shown that processes of denying humanness occur even if group antagonisms are nonviolent, as evident from studies in Belgium and Spain [...]. Much literature has, however, studied how dehumanization occurs before and during mass violence [...], demonstrating how these processes feed into violence" - L. Calissendorff, J. Brosché, R. Sundberg, Dehumanization amidst massacres: An examination of Dinka-Nuer intergroup attitudes in south Sudan, „Peace and Conflict: Journal of Peace Psychology" 25, 2019, nr 1, s. 37. 
zachowań destrukcyjnych. Wydawało się oczywiste, że musi istnieć jakiś zespół cech psychologicznych, może nawet jakiś syndrom osobowości, który odpowiada za tego typu tendencje i postawy. Nie każdy przecież, znajdując się w podobnych okolicznościach, byłby skłonny dopuścić się pewnych czynów, a jeśli już, to nie tak skrajnych i tragicznych w skutkach. Katalizatorem naukowego zwrotu w kierunku przeżyć wewnętrznych człowieka, jaki miał miejsce szczególnie w pierwszej połowie $\mathrm{XX}$ wieku, były więc $\mathrm{z}$ jednej strony akty przemocy na tle rasowym czy religijnym, $\mathrm{z}$ drugiej - proces głębokiego odczłowieczenia i planowa eksterminacja wybranych grup społecznych podczas I i II wojny światowej, a także narodziny wyjątkowo niebezpiecznych ideologii totalitarnych.

Ponieważ dokładna charakterystyka możliwych uwarunkowań dehumanizacji (i szerzej - przemocy) wykracza poza ramy objętościowe niniejszego artykułu i właściwie wymagałaby osobnej monografii, z konieczności podjęty temat zostanie ograniczony do wybranych — w mojej ocenie najważniejszych, a także najlepiej zweryfikowanych empirycznie - uwarunkowań psychologicznych. Odwołują się one często do odrębnych tradycji badań i już sam ich dobór jest zadaniem trudnym, niestety również subiektywnym. Co więcej, każda z nich ma niezwykle bogatą bazę bibliograficzną, co zmusza do znacznych uogólnień teoretycznych i nie zawsze usprawiedliwionej selekcji literatury. Mam jednak nadzieję, że proponowana przeze mnie prezentacja stworzy względnie spójny tok dociekań, pozwalający uchwycić najważniejsze mechanizmy psychologiczne. Zagadnienie odczłowieczania odwołuje się bowiem do różnych nurtów myślowych, w których wskazuje się nieco inne zależności. Wystarczy wspomnieć tradycję badań Alberta Bandury czy rozległe badania nad dehumanizacją i infrahumanizacją. Chcę podkreślić, że dehumanizację rozumiem tu jako wszelką formę oddziaływania na innych (lub siebie), która w efekcie prowadzi do zanegowania lub odebrania uczestnikom życia społecznego poczucia autonomii, podmiotowości i godności.

W dalszej części artykułu przedstawię ważniejsze wyjaśnienia gotowości do dehumanizacji, widziane z perspektywy podmiotu, a następnie przejdę do wybranych teorii lub badań, które tę perspektywę poszerzają, uwzględniając znaczenie niezwykle istotnych - choć nie zawsze branych pod uwagę - społecznych sił psychologicznych znajdujących się poza podmiotem. Swego czasu starałem się pokazać, że akty dehumanizacji, a szczególnie infrahumanizacji, w pewnym sensie przynależą do stałego repertuaru aktywności umysłu ludzkiego ${ }^{2}$. Jest to obecnie perspektywa dość oczywista w psychologii, tak więc aby nie powtarzać dostępnych powszechnie teorii, przypomnę tylko, że człowiek jako podmiot społeczny, uwikłany w sieć złożonych relacji, wymagających skomplikowanej i uciążliwej

${ }^{2}$ A. Citlak, Dehumanizacja - patologia czy permanentny stan ludzkiego umystu? Spojrzenie z perspektywy psychologii poznania społecznego, „Studia nad Autorytaryzmem i Totalitaryzmem” 37, 2015, nr 1, s. 13-34; idem, Psychologiczne i językowe uprzedmiotowienie obcych (stereotypizacja i dehumanizacja wrogów), „Studia nad Autorytaryzmem i Totalitaryzmem” 40, 2018, nr 4, s. $7-30$. 
analizy danych, niejako zmuszony jest do myślenia „na skróty”. Efektem tego są wypracowane $\mathrm{w}$ drodze ewolucji mechanizmy takiej orientacji w świecie, które niestety obfitują $\mathrm{w}$ procesy poznawcze o charakterze mocno dehumanizującym innych, opisane obszernie także $\mathrm{w}$ teorii tożsamości społecznej ${ }^{3}$ : uproszczona kategoryzacja poznawcza, akcentuacja podobieństw wewnątrzkategorialnych z pominięciem różnic osobniczych, negatywna stereotypizacja itp. Dehumanizacja przybiera wówczas formę subtelnego pozbawiania innych przynależnych im cech ludzkich (na przykład typowo ludzkich emocji, sumienia) lub przypisywania im zachowań i zdolności typowych dla zwierząt, a więc formę infrahumanizacji. Zjawiska te przybierają na sile szczególnie w warunkach konfliktów międzygrupowych i rywalizacji, na co niestety nie mamy większego wpływu. Innymi słowy, współczesne badania psychologiczne zmuszają nas do myślenia o dehumanizacji jako procesie zachodzącym o wiele wcześniej (i częściej) niż akty behawioralne.

\section{Dysfunkcje podmiotu jako źródło agresji i dehumanizacji}

Jedną z pierwszych, a jednocześnie najbardziej rozpowszechnionych, tradycji badawczych w tym obszarze była teoria charakteru autorytarnego Ericha Fromma, który przedstawił wyniki swoich prac w 1941 roku w Escape from Freedom. Były to rozległe badania, które najpierw prowadzono w szkole frankfurckiej, jeszcze przed wybuchem wojny, a następnie w USA, gdzie przeniosła się większość przedstawicieli tej szkoły po dojściu Hitlera do władzy w Niemczech.

Charakter autorytarny opiera się na dwóch pozornie sprzecznych tendencjach osobowości, mających swe źródło najpierw w doświadczeniach z dzieciństwa ${ }^{4}$, a następnie w procesach interakcji społecznej ${ }^{5}$, mianowicie sadyzmie i masochi$z^{2} i^{6}$. Osoba o charakterze sadomasochistycznym, z jednej strony, jest predysponowana do uległości, rezygnacji z własnego wewnętrznego świata i pragnień na rzecz poddania się bez reszty innym, z drugiej — czerpie głęboką psychiczną

${ }^{3}$ Należy tu wszakże podkreślić, że zjawiska typowe dla dyskryminacji grupy obcej, opisane w teorii tożsamości społecznej, nie są tożsame ze zjawiskiem dehumanizacji i infrahumanizacji.

${ }^{4}$ Fromm prowadził też badania nad meksykańskimi rodzinami i strukturą relacji — idem, Sozialpsychologischer Teil, [w:] Studien über Autorität und Familie. Schriften des Instituts für Sozialforschung, t. 5, red. M. Horkheimer, Paris 1936, s. 77-135; por. J. Duckitt, Authoritarianism and group identification: A new view of an old construct, „Political Psychology” 1989, nr 10, s. 63-84.

5 Szczególnie interesującą pracą Fromma są jego wydane nieco później rozprawy na temat charakteru społecznego: Arbeiter und Angestelte am Vorabend des Dritten Reiches. Eine sozialpsychologische Untersuchung oraz Psychoanalytische Charakterologie in Theorie und Praxis. Der Gessellschafts-Charakter eines mexikanischen Dorfes, wydane w 1989 roku w: Erich Fromm: Gesamtausgabe, t. 3. Empirische Untersuchungen zum Gessellschafts-Charakter, red. R. Funk, München 1989.

${ }^{6}$ A. Miller, Zniewolone dzieciństwo. Ukryte źródła tyranii, Poznań 2013; H. Richter, Zur Psychoanalyse der Rechtsradikalismus, [w:] Das Faschismus Syndrom: Zur Psychoanalyse der Neuen Rechten in Europa, red. E. Modena, Giessen 1998, s. 228-239. 
satysfakcję z możliwości odreagowania wewnętrznego cierpienia poprzez zadawanie bólu innym. Sadyzm i masochizm są splecione jako wymagające się wzajemnie wymiary osobowości.

W Niemczech szczególnie podatną na ideologię faszystowską była klasa średnia, której byt ekonomiczny i bezpieczna egzystencja stały pod znakiem zapytania po I wojnie światowej ${ }^{7}$. Według Fromma „osobowość Hitlera, jego nauki oraz system hitlerowski wyrażają skrajną formę struktury charakteru, który nazwaliśmy »autorytarnym«, i dzięki temu właśnie zdołał on tak potężnie przemówić do tych grup ludności, które były obdarzone mniej więcej podobną strukturą charakteru" 8 . Fromm wskazuje sadyzm i masochizm jako zasadnicze cechy charakteru autorytarnego, wraz z nimi głęboką psychologiczną predyspozycję do agresji, destrukcji i posłuszeństwa.

Specyficzne dla hitleryzmu gloryfikacja siły, żądza władzy, jedność i idealizacja własnego narodu, otwarte wyrażanie nienawiści politycznych i rasowych dla ludzi żyjących w zagrożeniu deklasacją stanowiły hasła szczególnie atrakcyjne. Kompensowały bowiem poczucie niższości, utożsamianie się z silnym wodzem zabezpieczało przed przeżyciem leku i bezsilności ${ }^{9}$.

Krótko mówiąc, u źródeł gotowości do działań, jakie miały miejsce w okresie dominacji faszyzmu w Europie, były dysfunkcje psychiczne osadzone na głębokim (podświadomym) poziomie emocji i pragnień człowieka. Był to więc wyjątkowo dysfunkcyjny i niebezpieczny typ osobowości.

Badania nad autorytaryzmem prowadzone z kolei na Uniwersytecie Berkeley pozwoliły wskazać pewien kompleks cech osobowości, określanej osobowością autorytarną. Wyniki prac Theodore'a Adorno, Elsy Frenkel-Brunswik, Daniela Levinsona i Nevitte'a Sanforda opublikowane w The Authoritarian Personality ${ }^{10}$ w dużym stopniu odwołują się do sadyzmu i masochizmu Fromma, szczególnie tendencji do ulegania autorytetom i posłuszeństwa władzy z jednoczesną gotowością do sadystycznej agresji, mającej źródło w represyjnym wychowaniu. Ponieważ agresja ta nie mogła być wyrażona wobec „kochających” rodziców, kierowano ją zazwyczaj na innych, zwłaszcza tych, których władza wskazywała jako niebezpiecznych lub wrogów. Pojęcie osobowości autorytarnej znalazło się bardzo szybko w centrum badań nad autorytaryzmem politycznym jako kluczowy

7 „[W]yniki badań systematycznie pokazują, że najbardziej autorytarne są osoby z niskim wykształceniem i/lub wywodzące się z rodzin o niskim poziomie wykształcenia" - K. Korzeniowski, Autorytaryzm i jego psychopolityczne konsekwencje, [w:] Podstawy psychologii politycznej, red. K. Skarżyńska, Poznań 2002, s. 69.

${ }^{8}$ E. Fromm, Ucieczka od wolności, Warszawa 1998, s. 210. Fromm wyróżniał kilka typów sadyzmu i masochizmu, na przykład Stalina sadyzm nieseksualny, u Himmlera sadyzm analno-tezauryzatorski, u Hitlera zaś także nekrofilię — idem, Anatomia ludzkiej destrukcyjności, Poznań 2014.

9 U. Jakubowska, Preferencje polityczne. Psychologiczne teorie i badania, Warszawa, 1999, s. $24-25$.

10 Th. Adorno et al., The Authoritarian Personality, New York 1950; Th. Adorno, Osobowość autorytarna, Warszawa 2010. 
termin wyjaśniający liczne zachowania destrukcyjne społecznie, a nade wszystko niebezpieczne z punktu widzenia politycznego i prawnego ${ }^{11}$. Obecnie wiadomo, że szczególną rolę ogrywa tutaj tak zwany autorytaryzm prawicowy, nie zaś wszelka forma autorytaryzmu ${ }^{12}$. Wspomniane cechy osobowości, a także podatność na niebezpieczne ideologie, wielokrotnie służyły do wyjaśnienia aktów dehumanizacji i agresji, a po pewnych modyfikacjach doczekały się nawet określenia „syndrom faszystowski” (niem. das Faschismus Syndrom) ${ }^{13}$. Wiadomo też, że akty odczłowieczania wizerunku grup społecznych wywołują większą gotowość u osób autorytarnych do stosowania przemocy, a nawet tortur wobec członków tych grup. Innymi słowy, dehumanizacja jako zjawisko społeczne, polityczne, jako element propagandy, jest dla nich istotnym mediatorem i stymulatorem takich zachowań ${ }^{14}$.

Zarówno prace Fromma, jak i Adorna pozostają w nurcie psychoanalizy Sigmunda Freuda, zgodnie z którą głównym motorem działań człowieka są siły nieświadome, a w tym wypadku — dysfunkcje psychiczne osadzone w podświadomości, poza możliwością ich kontroli przez jednostkę. Ten dynamiczny, a nawet hydrauliczny model osobowości dysfunkcyjnej znalazł szerokie zastosowanie w psychopatologii, tłumacząc z powodzeniem wiele destrukcyjnych tendencji ludzkich, dysocjacji, rozszczepienie osobowości (na przykład sadystów, psychopatów, morderców) itp. ${ }^{15} \mathrm{Na}$ nim opiera się także szeroko rozpowszechniona teoria frustracji — agresji, której rozładowanie indywidualne lub społeczne często wiąże się z poszukiwaniem kozła ofiarnego ${ }^{16}$. Licznych przykładów tego typu od dawna dostarcza psychologia kliniczna i psychopatologia, co wyraźnie pokazuje, że istnieje bezpośredni związek między tym rodzajem zaburzeń a gotowością do zachowań destrukcyjnych.

11 P. Suedfeld, M. Schaller, Autorytaryzm i Holokaust. Wybrane implikacje poznawcze i afektywne, [w:] Zrozumieć zagładę. Społeczna psychologia Holokaustu, red. L. Newman, R. Erber, Warszawa 2009, s. 65-84.

12 B. Altemeyer, Enemies of Freedom: Understanding Right-Wing Authoritarianism, San Francisco 1988; P. Radkiewicz, Autorytaryzm a brzytwa Okhama, Warszawa 2012; U. Jakubowska, O naturze preferencji politycznych. Perspektywa psychologiczna, Warszawa 2018.

13 Zob. szczególnie zbiór tekstów w Das Faschismus Syndrom: Zur Psychoanalyse der Neuen Rechten in Europa, w którym autorzy analizują podobne zjawiska w różnych krajach na świecie.

${ }^{14}$ M. Lindén, F. Björklund, M. Bäckström, What makes authoritarian and socially dominant people more positive to using torture in the war on terrorism?, „Personality and Individual Differences" 2016, nr 91, s. 98-101. Warto tu nadmienić, że związek autorytaryzmu z infrahumanizacją może być jednak osłabiany wzrostem poczucia własnej śmiertelności - M. Motyl, J. Hart, T. Pyszczynski, When animals attack: The effects of mortality salience, infrahumanization of violence, and authoritarianism on support for war, ,Journal of Experimental Social Psychology” 46, 2010, nr 1, s. 200-203.

15 M. Seligman, E. Walker, D. Rosenhan, Psychopatologia, Warszawa 2003; N. McWiliams, Diagnoza psychoanalityczna, Gdańsk 2008, s. 167-182. Choć oczywiście psychodynamiczne wyjaśnianie przyczyn wspomnianych zaburzeń to tylko jedno z możliwych we współczesnej psychologii.

16 R. Brown, Prejudice. Its Social Psychology, Oxford 1995, s. 13-34. 
Mimo wielu zalet przedstawiona perspektywa - a także inne podobne do niej — każą nam jednak myśleć o agresji i dehumanizacji w kategoriach głębokich zaburzeń psychicznych (szczególnie gdy mówimy o wysokim nasileniu autorytaryzmu) i przesuwa uwagę na margines życia społecznego — tam bowiem, a nie wśród normalnych, zdrowych ludzi należy szukać tego typu dysfunkcji. Jest to jednak poważne ograniczenie, znacząco utrudniające dotarcie do istoty wielu aktów nietolerancji czy przemocy. Interpretacja w kategoriach różnicy jakościowej powinna zostać co najmniej uzupełniona o interpretację w kategoriach różnicy ilościowej.

\section{Nasilenie cech i specyfika pracy umysłu}

Znaczącą zmianę myślenia $\mathrm{w}$ tej dziedzinie wprowadził już między innymi Milton Rokeach, publikując w 1960 roku wyniki badań w pracy The Open and Closed Mind. Chodziło bowiem już nie tyle o zaburzenia osobowości, ile o nasilenie pewnych cech w funkcjonowaniu poznawczym. Rokeach wprowadził pojęcie dogmatyczności umysłu, ale rozumianej przede wszystkim jako zmienna o charakterze ilościowym. Ustalono, że dogmatyzm występuje w różnym nasileniu u każdego człowieka, mniej lub bardziej determinując procesy zarówno poznawcze, jak i motywacyjno-behawioralne. Wprawdzie wysoki dogmatyzm miał tutaj podłoże osobowościowe, to znaczy — miał wynikać z poczucia lęku i zagrożenia, osadzonych na głębokim poziomie struktury psychicznej, jednak pojęcie zaburzeń psychicznych zeszło bardzo wyraźnie na plan dalszy. Pojęcie dysfunkcji dochodzi do głosu dopiero w sytuacji wysokiego poziomu dogmatyzmu, kiedy pojawia się niezdolność do dialogu, zrozumienia perspektywy innych, a także nadmierna radykalizacja i sztywność przekonań ${ }^{17}$, uprzedzenia i dyskryminacja z gotowością do agresji. Umysł dogmatyczny staje się podatny na ideologie uproszczone, radykalne z jednoznacznym wskazaniem niepodważalnego autorytetu.

W latach osiemdziesiątych i dziewięćdziesiątych XX wieku pojawiła się nowa, równie istotna perspektywa teoretyczna autorstwa Ariego Kruglanskiego i współpracowników, określana potrzebą domknięcia poznawczego ${ }^{18}$. Nasilenie tej potrzeby także jest przedstawiane na pewnym kontinuum, co oznacza, że choć

17 Już wtedy rozróżniano jednak sztywność poznawczą i dogmatyczność poznawczą — pierwsza miała się odnosić do pewnych aspektów myślenia lub pojedynczych przekonań, druga do organizacji wiedzy w umyśle; zob. M. Rokeach, W. McGovney, R. Denny, Dogmatic thinking versus rigid thinking. An experimental distinction, [w:] The Open and Closed Mind. Investigations into the Nature of Belief Systems and Personality Systems, red. M. Rokeach, New York 1960, s. 182-196.

18 A. Kruglanski, T. Freund, The freezing and unfreezing of lay inferences: Effects on impressional primacy, ethnic stereotyping, and numerical anchoring, „Journal of Experimental Social Psychology" 1983, nr 19, s. 448-468; A. Kruglanski, Y. Klar, Widok z mostu: integrowanie paradygmatów teorii zgodności i teorii atrybucji z perspektywy epistemologii naiwnej, [w:] Poznanie, afekt, zachowanie, red. T. Maruszewski, Warszawa 1993, s. 216-258; A. Kruglanski, D. Webster, Motivated closing of the mind: „, Seizing” and „freezing”, „Psychological Review” 1996, nr 103, s. $263-283$. 
występuje u każdego człowieka, to w różnym nasileniu. Potrzeba domknięcia odnosi się do poznania motywowanego ${ }^{19}$, czyli poznania, którego celem jest uzyskanie w miarę prędko pewnej i niezawodnej wiedzy, pozwalającej na podejmowanie szybkich i jednoznacznych decyzji. Wiedza tego typu jest szczególnie użyteczna w sytuacji niepewności, konieczności zajęcia wyraźnego stanowiska, ocenie zagrożenia czy w konfliktach grupowych. Wraz ze wzrostem motywacji do uzyskania domknięcia wzrasta niecierpliwość poznawcza, a także tworzenie sądów na podstawie mało konkluzywnych danych. Samo zdobywanie tej wiedzy obejmuje dwa procesy poznawcze: przechwytywanie mniej lub bardziej istotnych danych niezbędnych do utworzenia pewnego sądu (ang. seizing) oraz zamrożenie uzyskanego sądu/wiedzy, nadając mu charakter trwały (ang. freezing). Wysoki poziom tej potrzeby powoduje szczególną gotowość do posługiwania się wiedzą stereotypową, uproszczoną lub istniejącą już wcześniej w umyśle człowieka, a w odpowiednich warunkach może też sprzyjać dehumanizacji ${ }^{20}$. Szybkie utworzenie wiedzy skutkuje również niechęcią do dalszej jej weryfikacji, odpornością na kontrargumenty, a także niechęcią, konserwatyzmem, stereotypami i uprzedzeniami wobec osób myślących inaczej, z jednoczesną potrzebą stowarzyszania się z osobami o podobnych poglądach ${ }^{21}$.

Potrzeba domknięcia poznawczego wiąże się też $\mathrm{z}$ potrzebą struktury ${ }^{22}$ w poznaniu społecznym, polegającą na dążeniu do nadania złożonemu zestawowi informacji o świecie uproszczonego porządku i ładu. Psycholodzy wyróżniają tu potrzebę struktury specyficznej, to jest dążenia do poznania i porządkowania danych z uwzględnieniem przesłanek za i przeciw, mającego charakter dość racjonalny i wyważony, typowy dla większości ludzi, oraz potrzebę struktury niespecyficznej, to jest dążenia do nadmiernego porządkowania danych, wynikającego z napięcia psychicznego i innych uwarunkowań osobowościowych bądź sytuacyjnych ${ }^{23}$. W tym drugim wypadku dochodzi do uproszczenia obrazu świata w umyśle człowieka, odrzucenia interpretacji konkurencyjnych, możliwych,

19 D. Webster, A. Kruglanski, D. Pattison, Motivated language use in intergroup contexts, „Journal of Personality and Social Psychology” 1997, nr 72, s. 1122-1231.

20 N. Kteily, E. Bruneau, Darker demons of our Nature: The need to (re)focus attention on blatant forms of dehumanization, „Current Directions in Psychological Science” 26, 2017, nr 6, s. $487-494$.

21 T. Jost et al., Political conservatism as motivated social cognition, „Psychological Bulletin" 2003, nr 29, s. 339-375; J. Shah, A. Kruglanski, E. Thompson, Membership has its (epistemic) rewards: Need for closure effects on in-group bias, „Journal of Personality and Social Psychology" 1998 , nr 75, s. 383-393.

22 Aczkolwiek niektórzy odróżniają potrzebę struktury od ogólnych zdolności poznawczych; zob. A. Roets, A. VanHiel, Separating ability from need: Clarifying the dimensional structure of the need for closure scale, „Personality and Social Psychology Bulletin” 2007, nr 33, s. 266-280.

23 T. Freund, A. Kruglanski, T. Schpitzajzen, The freezing and unfreezing of impressional primacy: Effects of the need for structure and fear of invalidity, „Personality and Social Psychology Bulletin" 1985, nr 11, s. 479-487; A. Kruglanski, T. Freund, op. cit.; D. Bar-Tal, A. Raviv, A. Spitzer, The need and ability to achieve cognitive structuring: Individual differences that moderate the 
negacji stanowisk odmiennych niż własne ${ }^{24}$. Osoby z wysokim nasileniem potrzeby struktury i domknięcia wykazują większą gotowość do przyjmowania ideologii dwubiegunowych, jednoznacznych; cecha ta koreluje pozytywnie $\mathrm{z}$ autorytaryzmem, nietolerancją, uprzedzeniami i wrogością, co wybitnie sprzyja dehumanizacji wrogów ${ }^{25}$. Takie osoby wykazują większą tendencję do działań przewidywalnych i trwałych, a przyjęta przez nich wizja świata na płaszczyźnie zarówno etycznej, jak i ideologicznej staje się wyraźnie silniej spolaryzowana, pozbawiona sfery szarości lub tego, co niejednoznaczne ${ }^{26}$.

Nasilenie pewnych cech psychologicznych, a także wyjaśnianie gotowości do przyjmowania ideologii autorytarnych i zwiększonej podatności na akty infrahumanizacji w kategoriach nie tyle jakościowych, ile ilościowych cieszy się obecnie w psychologii społecznej i politycznej szerokim zainteresowaniem. Wskazano wiele zmiennych psychologicznych, które mogą istotnie warunkować te zachowania, jak chociażby orientacja na dominację społeczną ${ }^{27}$ czy złożoność integratywna ${ }^{28}$. Co więcej, wydaje się wysoce prawdopodobne, że predyspozycje do akceptacji ideologii radykalnych i skrajnych mogą mieć źródło w uwarunkowaniach genetycznych ${ }^{29}$. W świetle tego krótkiego zestawienia, a przede wszystkim w świetle częstości występowania dehumanizacji i infrahumanizacji należy przyjąć, że ich interpretacja w kategoriach patologii i zaburzeń osobowości

effect of stress on information processing, „Journal of Personality and Social Psychology” 1999, nr 77, s. 31-51.

24 S. Neuberg, J. Newsom, Personal need for structure: Individual differences in the desire for simple structure, ,Journal of Personality and Social Psychology” 1993, nr 65, s. 113-131.

25 „People high in need of closure report a preference for aggressive actions only when the ideological cues (e.g., shared beliefs, norms, and worldviews) suggest aggression as the most proper and desirable way of dealing with intergroup threat and conflict" - A. Golec de Zavala, A. Cisłak, E. Wesołowska, Political conservatism, need for cognitive closure, and intergroup hostility, „Political Psychology" 31, 2010, nr 4, s. 535.

26 M. Kossowska, Nowe poznawcze wymiary osobowości a społeczne poznanie $i$ działanie, [w:] Psychologia poznania spolecznego, red. M. Kofta, M. Kossowska, Warszawa 2009, s. 236-237; M. Kossowska, Umyst niezmienny. Poznawcze mechanizmy sztywności, Kraków 2005, s. 105-114.

27 J. Sidanius, F. Prato, Social Dominance: An Intergroup Theory of Social Hierarchy and Oppresion, New York 1999; J. Sidanius et al., Social dominance theory: Its agenda and method, „Political Psychology” 25, 2004, nr 6, s. 854-880; J. Trounson, Ch. Critchley, J. Pfeifer, Australian attitudes toward asylum seekers: Roles of dehumanization and social dominance theory, „Social Behavior and Personality" 2015, nr 43, s. 1641-1656; F. Prati et al., Predicting support for Arabs' autonomy from social dominance theory: The role of identity complexity and dehumanization, „Political Psychology" 37, 2016, nr 2, s. 293-301.

$28 \mathrm{Ph}$. Tetlock, Cognitive structural analysis of political rhetoric: Methodological and theoretical issues, [w:] Explorations in Political Psychology, red. S. Iyengar, W. McGuire, London 1993, s. 380-406; P. Suedfeld, Ph. Tetlock, Ingrative complexity at forty: Steps toward resolving the scoring dilemma, „Political Psychology” 2014, nr 35, s. 597-602. Zob. analiza zjawiska w języku polskim - U. Jakubowska, O naturze preferencji..., s. 119-124.

29 U. Jakubowska, W. Oniszczenko, The role of personality, cognitive, environmental and genetic factors as determinants of religious fundamentalism: A twin study in a Polish sample, „Studia Psychologica" 2010, nr 52, s. 253-263. 
odnosi się jedynie do niewielkiego marginesu. Problem jest jednak o wiele szerszy i wybiega daleko poza uwarunkowania podmiotowe.

\section{Niedoceniana rola dynamiki społecznej}

Badania psychologów społecznych bardzo szybko pokazały wiele istotnych niepodmiotowych źródeł, lub przynajmniej silnych katalizatorów, zachowań zarówno pro-, jak i antyspołecznych. Ich wspólną cechą jest umiejscowienie niejako poza działającym, ale uwikłanym w nie podmiotem. Na znaczącą rolę dynamicznie oddziałującego otoczenia społecznego w zachowaniu człowieka zwracał już uwagę Kurt Lewin ze swoją teorią pola ${ }^{30}$, wedle której każde zachowanie należy traktować jako funkcję osoby i otoczenia. Grupy społeczne tworzą układ pewnych współzależności, co daje o sobie znać w relacjach między jej członkami, ale też w relacjach międzygrupowych. Każda decyzja jednego członka grupy ma bowiem wpływ na całość jej funkcjonowania. Tworzy się przez to przestrzeń życiowa jako pole zderzenia przeróżnych sił psychologicznych, których wypadkową są trudne do przewidzenia reakcje ludzi bądź oddziaływanie nowych sił psychologicznych $^{31}$. W dalszej części pracy chciałbym zwrócić uwagę na szczególną rolę takich zmiennych, jak konformizm, posłuszeństwo, role społeczne, depersonalizacja podmiotu i syndrom grupowego myślenia.

\section{Konformizm i posłuszeństwo}

Badania nad konformizmem pokazały ponad wszelką wątpliwość, że w dynamice grupowej jednostka staje się podmiotem znacząco zależnym od postaw lub przekonań innych członków grupy. Zależność ta może być oczywiście większa lub mniejsza, nie ulega jednak wątpliwości, że może prowadzić do rezygnacji z własnych przekonań bądź zachowań na rzecz stanowiska zajmowanego przez większość grupy. Klasyczne eksperymenty Solomona Ascha z lat pięćdziesiątych $\mathrm{XX}$ wieku $^{32}$ zainicjowały setki podobnych badań na świecie, które zasadniczo

30 K. Lewin, Dynamic Theory of Personality, New York 1936; idem, Frontiers in group dynamics, „Human Relations” 1, 1947, nr 2, s. 5-41; idem, Resolving Social Conflicts and Field Theory in Social Science, Washington 1997.

31 Możliwość przewidywania potencjalnych trajektorii ludzkich zachowań stała się szczególnie kusząca na początku XXI, kiedy pojawiły się możliwości złożonej analizy danych i skomplikowane symulacje; zob. B. Latane, A. Nowak, J. Liu, Measuring emergent social phenomena: Dynamism, polarisation and clustering as order parameters of social systems, „Behavioral Science” 1994, nr 39, s. 1-24; J. Rączaszek-Leonardi, Symbols as constraints: The structuring role of dynamics and self-organization in natural language, „Pragmatics and Cognition” 17, 2009, nr 3, s. 653-676.

$32 \mathrm{~S}$. Asch, Effects of group pressure upon the modification of distortion of judgement, [w:] Group, Leadership and Men, red. W. Guetzkov, Pittsburg 1951, s. 76-92; S. Asch, Opinions and social pressure, „Scientific American” 1955, nr 193, s. 31-55. 
potwierdziły jego ustalenia. Dzisiaj wiemy, że konformizm zależy przede wszystkim od spójności i jednomyślności w grupie, a nade wszystko od jej wielkości (im mniejsza, tym większy jej wpływ - 4-10 członków wyzwala najsilniejsze tendencje konformistyczne), co wynika z intensywności wzajemnych relacji. Zależy on też od znaczenia, jakie jednostka przypisuje grupie, od jej cech osobowych, poczucia własnej wartości i potrzeby afiliacji. Istotną zmienną pośredniczącą, co podkreślają psychologowie międzykulturowi, okazuje się również typ społeczeństwa i kultury, w jakiej funkcjonuje grupa — zdecydowanie więcej zachowań konformistycznych wykazują osoby w kulturze kolektywistycznej, w której ,ja” podmiotu jest ściśle związane z pojęciem „my” i dobrem społecznym $^{33}$. Tam więc, gdzie rozwija się ideologia totalitarna, a szczególnie gdy jej elementy są prezentowane jako dobro ogólne czy narodowe, członkowie kultury kolektywistycznej mogą być bardziej podatni na jej wpływ. Wtedy bowiem rezygnacja z własnych przekonań na korzyść grupy stanowi dobro samo w sobie i jest traktowana jako objaw dojrzałości społecznej. Ponadto siła takiej ideologii staje się tym większa, im częściej w dyskursie publicznym podkreśla się dychotomię własnego, moralnego i pięknego świata w opozycji do tego, co istnieje poza nim (na przykład Niemcy-Żydzi, Polska-Europa, demokratyczna Ameryka-reżimowy Bliski Wschód). Przykładów ulegania presji grupowej jest obecnie niezliczona ilość, nie ma więc, jak sądzę, potrzeby specjalnie się nad nimi zatrzymywać. Warto natomiast wskazać, że jednym z bardziej zaskakujących paradoksów konformizmu i nacisku grupowego jest — również rzadko uwzględniany — realny wpływ mniejszości na większość. Otóż, realną siłę oddziaływania ma grupa mniejszościowa, pod warunkiem że jej poglądy są prezentowane przez dłuższy czas i zachowują spójność ${ }^{34}$. Grupy te w przeciwieństwie do większości wykorzystującej tak zwany wpływ normatywny, mogą oddziaływać na innych poprzez wpływ informacyjny ${ }^{35}$, równie skuteczny jak inne formy wpływu bądź nacisku społecznego. Zresztą historia niejednokrotnie była świadkiem właśnie takich przemian, kiedy to permanentny i zdeterminowany wpływ spójnej mniejszości doprowadzał do głębokich przemian politycznych czy nawet rewolucji.

Wpływ grupy, a właściwie jej autorytetów, na zachowanie jednostki pokazały w sposób szokujący również eksperymenty Stanleya Milgrama ${ }^{36}$ z lat 19611962, w których badani na polecenie eksperymentatora razili prądem inne osoby,

33 D. Meyers, Psychologia społeczna, Poznań 2003, s. 290-296.

34 A. Nowak, J. Szemrej, B. Latane, From private attitude to public opinion, „Psychological Review" 1990, nr 97, s. 362-376; S. Moscovici, Three concepts: Minority, conflict and behavioral style, [w:] Minority Influence, red. W. Moscovici, A. Mucchi-Faina, A. Maass, Chicago 1994, s. 233-251; W. Wood et al., Minority influence: A meta-analytic of social influence processes, „Psychological Bulletin” 1994, nr 115, s. 323-345.

35 E. Aronson. T. Wilson, R. Akert, Psychologia społeczna, Poznań 2006, s. 232-233.

36 S. Milgram, Behavioral study of obedience, ,Journal of Abnormal and Social Psychology" 1963, nr 67, s. 371-378; idem, Obedience to Authority: An Experimental View, New York 1974; zob. też idem, Posluszeństwo wobec autorytetu. Eksperyment, który wystawit na próbę ludzka 
karząc je za niepowodzenia w wykonaniu zadań. Rażenie prądem (które faktycznie nie miało miejsca, o czym nie wiedziały osoby badane) wzrastało od dawki 15 do $450 \mathrm{~V}$, i takie ładunki były aplikowane przez uczestników eksperymentu ze świadomością, że w końcowej fazie mogą być one śmiertelne. Nie ma potrzeby zamieszczać tu opisu szczegółów tego eksperymentu, są one powszechnie dostępne w literaturze, jednak faktem pozostaje, że odpowiednio zaaranżowane warunki, w jakich znajduje się podmiot, mogą wywołać tak silną presję psychologiczną, że zmusi ona nawet osoby sprzeciwiające się wewnętrznie tym nieludzkim zachowaniom do pełnego posłuszeństwa. Doświadczenie to pokazało jednoznacznie, że wpływ społeczny jest zjawiskiem o ogromnej sile oddziaływania i nie trzeba być psychopatą, sadystą, aby w akcie posłuszeństwa dokonać przerażających czynów. Istnieje obecnie wiele konkurencyjnych wyjaśnień tego zjawiska, aczkolwiek bez wątpienia kluczową rolę odgrywa tu rozproszenie lub co najmniej przesunięcie odpowiedzialności, która miała być niejako dzielona między osobą badaną a wiarygodnym eksperymentatorem i systemem „wychowawczym” wobec osoby karanej. Ważnym czynnikiem była też bliskość autorytetu, co zwiększało jego siłę oddziaływania i wiarygodność (w badaniu byli to pracownicy prestiżowego Uniwersytetu Yale). Równie silnym regulatorem posłuszeństwa okazał się dystans wobec ofiary, a także mniej lub bardziej zhumanizowany $\mathrm{z}$ nią kontakt. W różnych odmianach eksperymentu manipulacja dystansem i dehumanizacją relacji (widok cierpienia ofiary, odgłosy krzyków, możliwość dotyku itp.) istotnie regulowały gotowość do uległości i zadawania cierpienia. Co więcej, raz rozpoczęty proces zadawania cierpienia i dehumanizacji wydaje się coraz mniej wrażliwy na zahamowanie.

Siła posłuszeństwa wiąże się ściśle ze stopniową psychologiczną przemianą, wynikającą z coraz to dotkliwszej krzywdy, jaką wyrządza jednostka, oraz z trudnościami, jakie ma ona z przedefiniowaniem nieprzyjaznego autorytetu na całkowicie bezprawny, oraz podjęciem ostatecznej decyzji o przeciwstawieniu się takiemu autorytetowi ${ }^{37}$.

Eksperyment Milgrama, mimo krytyki ${ }^{38}$, doczekał się wielu wersji i modyfikacji $^{39}$. W większości z nich pokazano, że wpływ autorytetu i odpowiednia aran-

naturę, Sopot 2017; D. Doliński, T. Grzyb, Postuszni do bólu. O uległości wobec autorytetu 50 lat po eksperymencie Milgrama, Sopot 2017.

37 A. Miller, Postuszeństwo, [w:] Psychologia społeczna. Encyklopedia Blackwella, red. A. Manstaed, M. Hewstone, Warszawa 2001, s. 394.

38 Wypada nadmienić, że eksperymentom Milgrama zarzucano, po pierwsze, pogwałcenie zasad etyki pracy psychologa, polegające na niedoinformowaniu osób badanych o faktycznym celu i procedurze eksperymentu; po drugie, nadinterpretację i zawyżanie wyników - C. Herrera, Ethics, deception, and ,those Milgram Experiments”, „Journal of Applied Philosophy” 2001, nr 18, s. 245-256. Ponadto naciski eksperymentatora i jego stosunek do osoby badanej pozwalają sądzić, że również na tym polu była to relacja mocno zdehumanizowana, na co rzadziej zwraca się uwagę we współczesnej literaturze psychologicznej.

39 S. Gilbert, Another look at the Milgram obedience studies: The role of the graduated series of shocks, „Personality and Social Psychology Bulletin” 1981, nr 7, s. 690-695; W. Meeus, Q. Raaijmakers, Administrative obedience: Carrying out orders to use psychological-administra-

Studia nad Autorytaryzmem i Totalitaryzmem 41, nr 4, 2019

(C) for this edition by CNS 
żacja otoczenia społecznego może skutecznie pozbawiać jednostkę wewnętrznej siły i moralnych hamulców przed dokonaniem aktów skrajnej przemocy ${ }^{40}$. Warto nadmienić, że paradoksalnie pełne (z pewnymi obiekcjami) posłuszeństwo okazywali urzędnicy i gospodynie domowe. Wydaje się to niezwykle bliskie refleksjom Hannah Arendt na temat banalności zła, którego realizacja nie wymaga bestii w ludzkim ciele, ale często zwykłych, szanujących siebie i pewien porządek społeczno-etyczny ludzi ${ }^{41}$.

\section{Siła oddziaływania ról społecznych}

Wpływ odgrywanych ról społecznych, rozumianych jako realizacja ustalonego zbioru oczekiwań grupowych, wykazano wielokrotnie zarówno w psychologii, jak i dyscyplinach pokrewnych. Może on sięgać właściwie wszystkich wymiarów aktywności człowieka: poznawczego, emocjonalnego i behawioralnego ${ }^{42}$. Każda grupa oferuje swój zestaw funkcji do spełnienia, co wiąże się - z jednej strony - z dużymi gratyfikacjami i łatwiejszym dostępem do zasobów, z drugiej — większym zakresem oczekiwań i zobowiązań. Im większa złożoność grupy, tym większy zestaw możliwych do odgrywania ról i tym większy układ powiązań między nimi. W efekcie każda rola społeczna (rodzica, dyrektora, premiera) pozostaje w ścisłym splocie powiązań, zależnych od akceptowanych norm społeczno-kulturowych. Zasadniczo teoria ról społecznych ${ }^{43}$ pozwala lepiej zrozumieć wzajemną dynamikę grupy i zachowań jej członków, a także zidentyfikować strukturę wzajemnych konstelacji przydzielonych — mniej lub bardziej wyraźnie — zadań. Wpływ pełnionych funkcji niesie z sobą jednak znaczące konsekwencje psychologiczne, istotne z punktu widzenia podjętych tu rozważań. Przede wszystkim może wyzwalać niezwykłą dynamikę zmian na poziomie jednostkowym i grupowym. Zmiany behawioralne, jakie zazwyczaj obserwujemy u osób podejmujących się nowych ról, są bowiem dość oczywiste, ale zaskakują nas, gdy

tive violence, „European Journal of Social Psychology” 1986, nr 16, s. 311-324; J. Burger, Replicating Milgram. Would people still obey today?, „American Psychologist” 64, 2009, nr 1, s. 1-11.

40 T. Blass, Understanding behavior in the Milgram obedience experiment: The role of personality, situations, and their interactions, „Journal of Personality and Social Psychology” 1991, nr 60, s. 398-413; A. Miller, What can the Milgram obedience experiments tell us about the Holocaust? Generalizing from the social psychology laboratory, [w:] The Social Psychology of Good and Evil, red. A. Miller, New York 2004, s. 193-239.

41 H. Arendt, Eichmann w Jerozolimie. Rzecz o banalności zła, Warszawa 2010.

42 B. Biddle, Role Theory: Expectancies, Identities, and Behavior, New York 1979; J. Bosak, S. Sczesny, A. Eagly, The impact of social roles on trait judgments: A critical re-examination, „Personality and Social Psychology Bulletin” 2012, nr 38, s. 429-440.

43 R. Turner, Role-taking: Proces vs conformity, [w:] Human Behavior and Social Process, red. A. Rose, Boston 1962; A. Eagly, W. Wood, Social role theory, [w:] Handbook of Theories in Social Psychology, red. P. van Lange, A. Kruglanski, E. Higgins, Thousand Oks 2012, s. 458-476. 
wymykają się kontroli lub prowadzą do zaburzeń percepcji społecznej albo relacji społecznych $^{44}$.

Najbardziej spektakularnym przykładem zaburzeń nie tylko percepcji i emocji, lecz także zachowań jest powszechnie znany eksperyment symulowanego więzienia Philipa Zimbardo, przeprowadzony w podziemiach Uniwersytetu Stanforda w USA ${ }^{45}$. Losowo podzieleni ochotnicy (studenci, bez zaburzeń psychicznych, bez konfliktów z prawem) mieli odgrywać role strażników i więźniów przez dwa tygodnie. Niestety kumulacja agresji, poniżenia, znęcania się i dehumanizacji ze strony strażników, jak też bierności, depresji, nienawiści i dysfunkcji emocjonalnych więźniów zmusiła psychologów do przerwania eksperymentu po sześciu dniach. Stał się on chyba najbardziej znanym przykładem, wielokrotnie wskazywanych potem w badaniach, głębokich zmian osobowości osób pełniących określone funkcje społeczne, a także zmian wewnątrzgrupowych i międzygrupowych. Oczywiście zmiany te były wzmocnione poczuciem konfliktu międzygrupowego ${ }^{46}$, jednak ogólny wynik eksperymentu pokazał, że identyfikacja z rolą w odpowiednich zaaranżowanych warunkach może wyzwalać siły psychologiczne wymykające się całkowicie kontroli nie tylko ze strony jednostki, ale grupy społecznej ${ }^{47}$. Siły te mogą w prostej linii prowadzić do wzajemnego pozbawienia się poczucia człowieczeństwa i wyniszczenia. Identyfikacja z odgrywaną rolą społeczną ma znaczenie wyjątkowe, a w wypadku ról obdarzonych władzą bądź autorytetem może stanowić przemożne narzędzie zarówno pozytywnego, jak i negatywnego wpływu ${ }^{48}$.

44 Przykładowo osoby pełniące funkcje niższego szczebla są zazwyczaj oceniane jako mniej inteligentne, mniej zaradne, mniej kompetentne, podczas gdy osoby odgrywające role wyższego szczebla - przeciwnie, a co ciekawe, zjawisko to występuje nawet w sytuacji losowego przydziału ról w eksperymentach, w których uczestnicy mają świadomość, że to jedynie „gra” na potrzeby badań. Podobnie wpływ odgrywanej w badaniu roli wyraźnie rzutuje na lepsze lub gorsze wyniki w rozwiązywaniu zadań poznawczych — L. Messe, N. Kerr, D. Sattler, „But same animals are more equals than others". The supervisor as a privileged status in group contexts, [w:] Group Processes and Productivity, red. S. Worchel, W. Wood, J. Simpson, Newbury Park 1992; E. Langer, A. Benevento, Self-induced dependence, ,Journal of Personality and Social Psychology” 1978, nr 36, s. 886-893; zob. też D. Meyers, op. cit., s. 257.

45 C. Haney, C. Banks, Ph. Zimbardo, Więźniowie i strażnicy - badanie w symulowanym więzieniu, [w:] Człowiek istota społeczna. Wybór tekstów, red. E. Aronson, Warszawa 2002, s. 83-101.

46 B. Wojciszke, D. Doliński, Psychologia społeczna, [w:] Psychologia akademicka, t. 2, red. J. Strelau, D. Doliński, Gdańsk 2010, s. 442.

$47 \mathrm{Ph}$. Zimbardo, Efekt Lucyfera. Dlaczego dobrzy ludzie czynia zło?, Warszawa 2008.

$48 \mathrm{~W}$ ostatnich latach kilku uczestników eksperymentu zaczęło donosić o subtelnym stymulowaniu przez Zimbardo zachowań agresywnych lub pomijaniu w późniejszych opisach i sprawozdaniach - a zgłaszanych przez nich — zachowań symulowanych dla lepszego efektu całego badania. Rzuca to cień na wiarygodność badania i ogólnego wyniku; zob. https://www.livescience.com/62832-stanford-prison-experiment-flawed.html (dostęp: 28.09.2019); https:/www.newsweek.pl/wiedza/nauka/stanfordzki-eksperyment-wiezienny-zaskakujace-fakty-po-latach/6md8c96 (dostęp: 28.09.2019). Sądzę, że fakty te nie zmieniają jednak ogólnej tendencji do zachowań agresywnych i dehumanizacji wskazanych przez Zimbardo, choć prawdopodobnie w mniejszym nasileniu niż przedstawiał to przez lata amerykański psycholog. 
Ważnym na gruncie psychologii społecznej eksperymentem, który znacząco uzupełnia przedstawioną perspektywę, były doświadczenia przeprowadzone przez Alberta Bandurę i jego współpracowników dotyczące zachowań agresywnych (między innymi rażenia prądem) ${ }^{49}$. W eksperymencie manipulowano poczuciem odpowiedzialności (osobistej bądź rozproszonej), a także dehumanizacją osób karanych („ofiary” przedstawiano w sposób neutralny, zdehumanizowany lub zhumanizowany). Obie zmienne okazały się skutecznym czynnikiem katalizującym zachowania agresywne, szczególnie gdy inni byli postrzegani jako podmiot zdehumanizowany, a odpowiedzialność badanych została rozproszona. Ważnym elementem tych badań było dość subtelne ,zawieszenie” zasad etycznych, które sprzyjało ujawnianiu agresji.

dehumanizacja, rozproszenie odpowiedzialności a wysokość kary wg A. Bandury

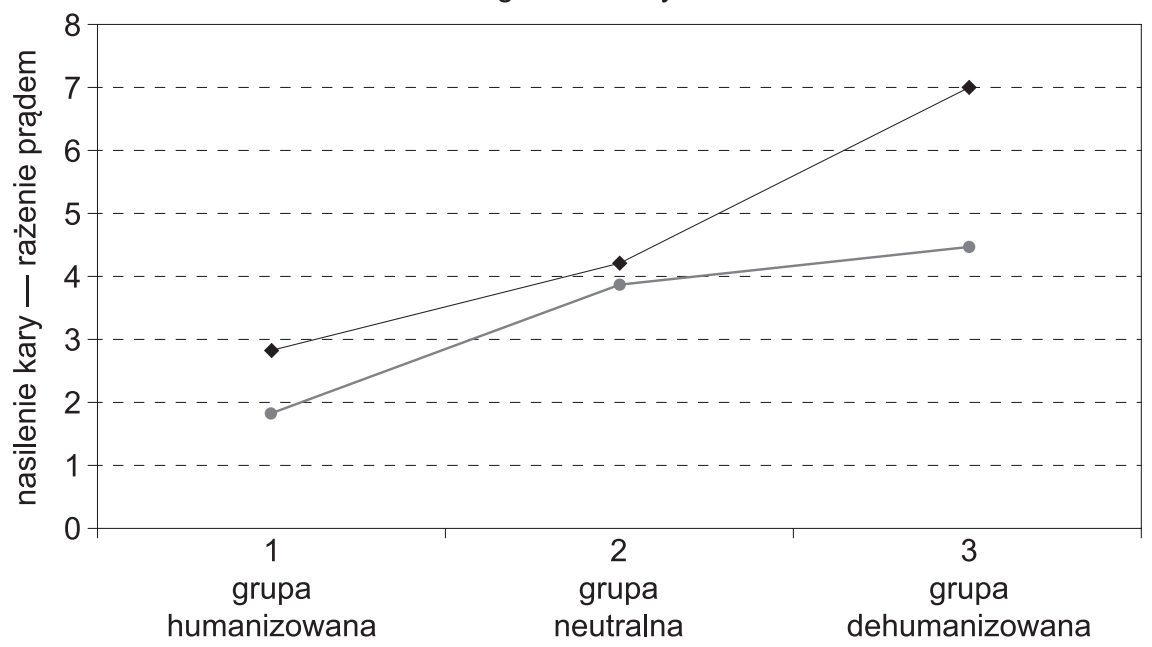

Wykres 1 . Zależność między wysokością stosowanej kary a wizerunkiem podmiotów społecznych (humanizowany, neutralny, zdehumanizowany) i poczuciem odpowiedzialności osobistej (linia dolna) lub grupowej/rozproszonej (linia górna)

Źródło: opracowanie własne na podstawie badań Bandury z 1975 roku.

\section{Depersonalizacja podmiotu}

Eksperymenty Milgrama, Zimbardo i Bandury pokazały, że jednostka w procesie specyficznych interakcji społecznych może zatracić nie tylko wyznawane przez siebie normy moralne, lecz także poczucie własnego, dotychczasowego ,ja”.

49 A. Bandura, B. Underwood, M. Fromson, Disinhibition of aggression through diffusion of responsibility and dehumanization of victims, „Journal of Research in Personality” 1975, nr 9, s. 253-269.

Studia nad Autorytaryzmem i Totalitaryzmem 41, nr 4, 2019

(C) for this edition by CNS 
W mniejszym stopniu, to znaczy bez tak dramatycznych zmian psychologicznych, aczkolwiek niezwykle brzemiennych w skutkach, zjawisko zmian behawioralnych widać na przykładzie ruchów masowych. Uczestnictwo w wiecach kulturalnych, dużych imprezach sportowych, koncertach itp. zapewnia uczestnikom silne emocje i poczucie specyficznej więzi z grupą, co często pozwala doznać partycypacji w czymś większym, znaczącym i wyjątkowym. Uczestnictwo w masowych wydarzeniach o charakterze religijnym lub politycznym sprzyja subiektywnemu włączeniu się w system uniwersalnych wartości, słusznych idei, a możliwość wykonywania tych samych rytuałów dodatkowo katalizuje te doznania ${ }^{50}$. Mimo wielu pozytywnych aspektów, uczestnictwo w ruchach o charakterze masowym wyzwala jednak też wspomniane poczucie anonimowości i dezindywidualizacji, a one z kolei, przy odpowiednim splocie uwarunkowań (lub niestety przy celowej aranżacji wydarzeń), mogą prowadzić do zachowań wykraczających daleko poza ustalone normy społeczne. Tak na przykład duże grupy sprzyjają poczuciu anonimowości i rozproszeniu odpowiedzialności, przez co łatwiej dochodzi wówczas do aktów wandalizmu, przemocy, i to zarówno na poziomie inicjacji zachowań, jak i ich nasilenia. Zjawisko działań masowych opisywali już Gustave LeBon w Psychologii ttumu i William McDougall w The Group Mind, wskazując na coś w rodzaju duszy tłumu, która rozpala się z niebywałą łatwością, rozbudzając skrajne emocje czy prymitywne reakcje, ograniczając jednocześnie zdolność racjonalnej oceny sytuacji. Tłum reaguje gwałtownie, a raz ujawnione działania mają tendencję do niekontrolowanej eskalacji ${ }^{51}$. Przynajmniej częściową prawdziwość tych twierdzeń weryfikują codzienne obserwacje życia publicznego, historia i dokumenty, ale zostały one też szeroko opisane przez psychologów.

Zmiany na poziomie zachowań grupowych (masowych) lub — nieco inaczej — poważne zmiany w funkcjonowaniu jednostki na skutek oddziaływania dynamiki grupowej wyjaśnił bardzo trafnie John Turner w teorii autokategoryzacji (ang. self-categorization theory) ${ }^{52}$. Jego koncepcja, która wyrosła na gruncie teorii tożsamości społecznej (ang. social identity theory) Henriego Tajfela i jako jej uzupełnienie, wskazuje różne rodzaje kategoryzacji ,ja” przez człowieka w zależności od uwarunkowań poznawczo-środowiskowych ${ }^{53}$. Procesy kategoryzacji ,ja” zachodzą na trzech poziomach: ,ja” jest włączone przez umysł do kategorii

50 M. Ross, The relevance of culture for the study of political psychology and ethnic conflict, „Political Psychology” 1997, nr 18, s. 299-326.

51 G. LeBon, Psychologia ttumu, Warszawa 1986; W. McDougall, The Group Mind, London 1921.

52 J. Turner, Social categorization and the self-concept: A social cognitive theory of group behaviour, [w:] Advances in Group Processes, t. 2. Theory and Research, red. E. Lawler, Greenwich 1985, s. 77-122; J. Turner et al., Rediscovering the Social Group: A Self-Categorization Theory, Oxford 1987; J. Turner et al., Self and collective: Cognition and social context, „Personality and Social Psychology Bulletin" 1994, nr 20, s. 454-463.

53 M. Hornsey, Social identity theory and self-categorization theory: A historical review, „Social and Personality Psychology Compass" 2008, nr 2, s. 204-222. 
„ludzie”, to znaczy włączone do kategorii uniwersalnej, typowej dla całego rodzaju ludzkiego, do kategorii „my”, czyli grupy społecznej, z którą się identyfikujemy, i identyfikowane poznawczo jako niepowtarzalny byt psychologiczny, to jest podmiot różniący się w istotnych kwestiach od innych.

Zasługą Turnera było wskazanie i wielokrotne potwierdzenie empiryczne, że kategoryzacja ,ja" zachodzi bardzo dynamicznie i zmienia się między innymi w zależności od poznawczej dostępności danej kategorii w umyśle człowieka. Co więcej, kategoryzacja na każdym z tych poziomów wyzwala inną treść dotyczącą ,ja”, redefiniując je w sposób dynamiczny. „Ja” staje się czymś innym jako niezależny podmiot, a innym jako część kategorii „my” (katolicy, muzułmanie, LGBT, demokraci itp.) czy jako część kategorii uniwersalnych ${ }^{54}$. Jedną z ważniejszych konsekwencji rekategoryzacji ,ja” z poziomu niepowtarzalnego podmiotu do grupy społecznej jest zanik treści typowych dla ,ja” podmiotowego. Typowe ,ja” jako oś osobowości z przyjętym systemem znaczeń w pewnym sensie rozpływa się w „my”, przyjmując mniej lub więcej jego charakterystyk. Turner nazywa to zjawisko depersonalizacją podmiotu i traktuje jako kluczowy mechanizm poznawczy, który odpowiada nie tylko za faworyzację swoich, deprecjację obcych, stereotypy, konformizm, spójność grupową itp. ${ }^{55}$, lecz przede wszystkim za większość destrukcyjnych aktów grupowych ${ }^{56}$. Depersonalizacja zachodzi we wspólnocie (szczególnie w aktywnie działającym tłumie) niestety dość automatycznie, pozbawiając uczestnika zdolności do głębszej autorefleksji i odniesienia własnych działań do wyznawanego na co dzień systemu wartości. O wiele łatwiej wówczas o działania ryzykowne bądź nieetyczne, dyktowane wolą thumu, w którym rozpływa się ,ja”. Depersonalizacja jest często indukowana etapami, bywa stałym elementem życia w organizacjach o charakterze autorytarnym, takich jak wojsko, zakład poprawczy, obóz pracy, więzienie, sekty czy grupy o charakterze ekstremistycznym. Podmiot traci w nich dotychczasowe imię, przyjmuje nowe lub otrzymuje numer identyfikacyjny, jego wygląd zostaje zunifikowany (ogolona głowa, uniform, gesty itp.), pozbawiony rzeczy osobistych, nie wyraża swego zdania, bezwzględnie uznaje autorytet przywódcy. W zależności od rodzaju grupy depersonalizacja uzyskuje mniej lub bardziej wyraziste i brutalne formy.

54 N. Ellemers, R. Spears, B. Doosje, Self and social identity, „Annual Review of Psychology" 2002, nr 53, s. 161-186; Q. Huynh, T. Devos, H. Altman, Boundaries of American identity: Relations between ethnic group, prototypicality and policy attitudes, „Political Psychology” 2015, nr 36, s. 449-468.

55 J. Falomir-Pichastor, G. Mugny, Threatening intergroup relationships personal versus group-related moderators of conformity as a function of the level of self-categorization, „Social Psychology" 2, 2011, nr 4, s. 279-291; V. Iacoviello, F. Lorenzi-Cioldi, Self-depersonalization and ingroup favoritism in minimal group hierarchies, „Swiss Journal of Psychology” 77, 2018, nr 1, s. $5-14$.

56 J. Turner et al., Rediscovering the social group...; M. Verkuyten, L. Hagendoorn, Prejudice and self-categorization: The variable role of authoritarianism and ingroup stereotypes, „Personality and Social Psychology Bulletin" 1998, nr 24, s. 99-110. 
W wypadku aktywności tłumu, któremu towarzyszy choćby minimalne (milczące bądź symboliczne) przyzwolenie na przejawy agresji, bardzo łatwo jednak o wzrost przemocy, wandalizm grupowy, publiczne lincze, uczestnictwo w aktach pogromu, ludobójstwie, a nawet w orgiach seksualnych. Mają one bowiem wspólne podłoże psychologiczne - depersonalizację ,ja” uczestników, która odcina ich od poczucia etycznego i osobistej odpowiedzialności. Warto tu nadmienić, że uczestnictwo w tego typu aktach może być również jednym $\mathrm{z}$ istotnych źródeł poczucia siły i mocy, na co zwracał uwagę prawie sto lat temu polski psycholog Władysław Witwicki w swojej teorii kratyzmu (dążenia do poczucia mocy) ${ }^{57}$, co $\mathrm{w}$ połączeniu $\mathrm{z}$ teorią autokategoryzacji jawi się jako zjawisko niezwykle znaczące. Przeżycie poczucia mocy wraz zatraceniem ,ja” i zanikiem poczucia moralnego w odpowiednich okolicznościach może bowiem wywołać (i niestety wywołuje) reakcje skrajnie destrukcyjne.

Czy wobec tego rację mieli LeBon i McDougall, mówiąc, że thum jedynie wyzwala reakcje pierwotne i prymitywne, które — jak dodałby Freud - tkwią od zawsze na dnie psychiki człowieka w postaci pierwotnych instynktów śmierci (powstrzymywanych jedynie przez system wartości kulturowych), czy może jednak są one (reakcje) efektem splotu okoliczności, w jakich znajdują się tłumy? Pytanie to pozostaje raczej kwestią otwartą. Niemniej depersonalizacja podmiotu stanowi jedno z większych wyzwań współczesności, w niej bowiem bardzo często jednostka odnajduje silne emocje lub poczucie zjednoczenia $z$ grupą i zestawem jej symbolicznych znaczeń. Dzięki nim może odzyskać zagubione poczucie sensu, a także miejsce w świecie społecznym do granic możliwości zindywidualizowanym i wyalienowanym ${ }^{58}$. Depersonalizacja nie przynależy jedynie do świata antycznego czy średniowiecza, przepełnionych aktywnością wielkich wspólnot, ale jest integralną częścią życia religijnego, politycznego i artystycznego również dzisiaj.

\section{Syndrom grupowego myślenia}

Wpływ grupy na człowieka obejmuje nie tylko emocje i zachowania, wyzwalając bardziej instynktowne reakcje. Może też dogłębnie modyfikować procesy racjonalnego myślenia, prowadząc do nieadekwatnej oceny rzeczywistości i w konsekwencji podejmowania błędnych lub nawet katastrofalnych w skutkach

57 W. Witwicki, Z psychologii stosunków osobistych, „Przegląd Filozoficzny” 1907, nr 10, s. 531-537; idem, Psychologia, t. 2, Warszawa 1963.

58 S. Bruce, Fundamentalizm, Warszawa 2006; M. Środa, Indywidualizm i jego krytycy: współczesne spory między liberałami, komunitarianami i feministkami na temat podmiotu, wspólnoty i ptci, Warszawa 2009; zob. też S. Goldhill, Wielkie Dionizja a ideologia obywatelska, [w:] Antropologia antyku greckiego, oprac. W. Lengauer, L. Trzcionkowski, red. W. Lengauer, P. Majewski, L. Trzcionkowski, Warszawa 2011; oraz J. Griffin, Społeczna funkcja tragedii attyckiej, [w:] Antropologia antyku greckiego... 
decyzji ${ }^{59}$. Skrajna postać tego zjawiska, nazywana syndromem grupowego myślenia (ang. the syndrome of groupthinking), ma miejsce dość często, gdy członkowie grupy tworzą wspólnotę o dużym poczuciu spójności i siły. Syndrom ten, zidentyfikowany i opisany po raz pierwszy przez Irvinga Janisa ${ }^{60}$ na podstawie analiz procesu podejmowania decyzji przez rząd USA, a wcześniej zespoły doradcze prezydentów, okazał się problemem o tyle poważnym, o ile zadziwiającym — nie miał bowiem prawa zaistnieć przy tak kompetentnych zespołach doradców na najwyższych szczeblach władzy politycznej. A jednak syndrom grupowego myślenia pojawia się dość często w organizacjach biznesowych ${ }^{61}$, religijnych $^{62}$, militarnych ${ }^{63}$, politycznych i innych. Zagrożone są nim szczególnie takie grupy, które cechuje duża spójność wewnętrzna, izolacja od świata zewnętrznego (szczególnie izolacja od poglądów sprzecznych z grupowymi), autorytarny lider i poczucie zewnętrznego zagrożenia. W takich warunkach łatwo o „włączenie się” syndromu, który w skrócie polega na tym, że myślenie pojedynczych członków grupy zostaje poddane dążeniu do podtrzymania spójności i solidarności grupowej, wyłączając ich zmysł krytyczny ${ }^{64}$. Myślenie jednostki zostaje zespolone z subiektywnym poczuciem nadrzędnej jedności i słuszności działań grupy. Są to działania bezdyskusyjnie konieczne, podbudowane niezaprzeczalnymi wartościami („Gott mit uns”, „Bóg, honor, ojczyzna”, „dekomunizacja życia politycznego”, „sprawiedliwość społeczna” itp.), wszelkie ataki lub krytyka działań grupy stają się błędami i nie należy brać ich pod uwagę. Co więcej, należy się jej przeciwstawić. Hamulcem krytyki staje się wewnętrzna cenzura myślenia przeciwnego, co bardzo skutecznie powstrzymuje jej członków przed wyrażaniem zastrzeżeń czy wątpliwości. Naturalnym efektem takiego procesu jest złudzenie jednomyślności, odporności na atak, a także złudzenie siły, co wywołuje iluzoryczne poczucie słuszności decyzji.

Syndrom grupowego myślenia nie pozwala dostrzec realnych zagrożeń, sprzyja podejmowaniu decyzji niebezpiecznych niestety nie tylko dla grupy, ale w wypadku rządów decyzji zgubnych dla ogółu społeczeństwa. Obiektywna ocena sytuacji lub zagrożenia zostaje poddana nie tylko ułudzie jedności grupowej,

59 M. Turner, A. Pratkanis, A social identity maintenance model of groupthink, „Behavior and Human Decision Processes" 73, 1998, nr 2-3, s. 210-235.

60 I. Janis, Victims of Groupthink, Boston 1972; idem, Groupthink: Psychological Studies of Policy Decisions and Fascoes, Boston 1982.

${ }^{61}$ M. Hällgren, Groupthink in temporary organizations, „International Journal of Managing Projects in Business" 3, 2010, nr 1, s. 94-109.

62 M. Bell, First century groupthink: An exegetical case study, „Journal of Biblical Integration in Business" 19, 2016, nr 1, s. 26-37.

63 A. Mintz, I. Schneidermann, From groupthink to polythink in the Yom Kippur war decisions of 1973, „European Review of International Studies” 5, 2018, nr 1, s. 48-66.

64 D. Packer, Avoiding groupthink: Whereas weakly identified members remain silent, strongly identified members dissent about collective problems, „Psychological Science” 20, 2009, nr 5, s. 546-548. 
lecz także negatywnym stereotypom wroga, które zazwyczaj powodują jego marginalizację lub deprecjację. Wróg staje się głupi, niemoralny, niezdolny do sukcesu i słaby. Ułuda własnej skuteczności zamyka oczy na możliwe dramatyczne konsekwencje takich decyzji, jak na przykład w wypadku podjęcia decyzji przez rząd USA o inwazji na Kubę w 1961 roku, inwazji na Koreę Południową w 1950 roku, zlekceważeniu zagrożenia japońskiego i ataku na Pearl Harbor, zlekceważeniu opinii ekspertów i podjęciu decyzji o starcie wahadłowca Challanger ${ }^{65}$, błędów decyzyjnych podczas wojny w Iraku ${ }^{66}$ itp. $^{67}$

Zjawiskiem tym zagrożone są właściwie wszystkie rodzaje grup, od rodziny zaczynając, przez grupy rówieśnicze i zawodowe, na najwyższych szczeblach wyspecjalizowanych grup doradczych kończąc. Nie trzeba jednak specjalnie dowodzić, że szczególnie narażone są na nie grupy polityczne i religijne o radykalnych poglądach, z tendencją do dychotomizacji świata i silnym lub autorytarnym liderem. Spełniają one pewne warunki, dzięki którym o wiele łatwiej paść ofiarą psychologicznej dynamiki działań grupowych.

Syndrom grupowego myślenia jest też ściśle związany z tak zwaną polaryzacją grupową i przesunięciem ryzyka, co objawia się tym, że stanowiska członków grupy po wzajemnej konsultacji bardzo często radykalizują się i grupa jako całość wykazuje większą gotowość do podejmowania działań bardziej ryzykownych (o ile oczywiście wstępnie członkowie zajmowali podobne, choć mniej radykalne stanowiska). Objawia się to zarówno na poziomie radykalizacji decyzji lub ocen moralnych, które mogą stać się bardziej surowe, na poziomie decyzji politycznych, które mogą stawać się bardziej skrajne, czy też religijnych, które mogą przesunąc się w kierunku fanatyzmu. Dynamika interakcji grupowych sprzyja wzmocnieniu własnego stanowiska na skutek przede wszystkim wymiany podobnej argumentacji w grupie i zacieśniania więzi ludzi o podobnych poglądach. Polaryzacja nasila się jeszcze bardziej w warunkach napięć międzygrupowych, gdy do głosu dochodzą negatywne stereotypy deprecjonujące kompetencje wroga i generalnie jego wizerunek. Co więcej, polaryzacji przekonań i gotowości do niebezpiecznych działań towarzyszy również polaryzacja afektywna, to znaczy nasilenie przeżywanych emocji wobec osób/grup/faktów, co w wypadku konfliktów lub w okresach niepokojów politycznych negatywizuje stosunki społeczne, a także wyzwala liczne dodatkowe napięcia. Destabilizuje to poczucie społecznego zaufania i bezpieczeństwa, nasilając spiralę wcześniejszych mechanizmów

65 J. Esser, J. Lindoeffer, Groupthink and the space shuttle Challenger accident: Toward a quantitative case analysis, ,Journal of Behavioral Decision Making” 1989, nr 2-3, s. 167-177.

66 D. Badie, Groupthink, Iraq, and the war on terror: Explaining US policy shift toward Iraq, „Foreign Policy Analysis” 6, 2010, nr 4, s. 277-296.

67 Zob. literatura w języku polskim: E. Aronson, T. Wilson, R. Akert, Psychologia społeczna. Serce i umyst, Poznań 1997, s. 379-382; T. Tyszka, Psychologiczne pułapki oceniania i podejmowania decyzji, Gdańsk 2000, s. 58-64. 
psychologicznych. Nałożenie się tych zjawisk potrafi bardzo skutecznie „zaślepić" nawet doświadczone zespoły doradców i ekspertów politycznych, a co dopiero przeciętnego uczestnika życia społeczno-politycznego, zaangażowanego w debaty i wydarzenia polityczne.

\section{Wnioski}

Dominująca przez wiele lat perspektywa podmiotu jako głównego źródła destrukcyjnych relacji społecznych odnosi się jedynie do wąskiego zakresu tego typu zjawisk i może wyjaśniać tylko niewielką liczbę takich faktów. Zresztą przenoszenie wyjaśnień z poziomu jednostkowego na społeczny jest z metodologicznego punktu widzenia błędem. Zaburzenia osobowości, patologie, sadyzm, personalne uwarunkowania agresji, choć ważne, powinny być traktowane $\mathrm{w}$ analizie zjawisk społecznych jedynie jako uzupełnienie. Od dawna bowiem, szczególnie na gruncie psychologii społecznej, podkreśla się niezwykłą rolę dynamiki grupowej i znaczenie sił psychologicznych, z których zazwyczaj nie zdajemy sobie sprawy, a jeśli już, to nie bierzemy ich specjalnie pod uwagę jako realnego zagrożenia. A są to siły o przemożnym wpływie na jednostki i całe grupy społeczne, siły, które nie tylko determinują życie ludzkie, lecz bardzo często przejmują nad nim kontrolę. Niestety w niniejszym artykule z racji podjętego tematu skupiłem się na zjawiskach o charakterze negatywnym, co oczywiście czyni nieco jednostronną całość prezentacji. Zagadnienie to jest jednak zbyt rozległe, aby w jednym miejscu omówić także pozytywny wpływ dynamiki grupowej.

Dynamika grupowa jest zjawiskiem szczególnej wagi, której powinno się poświęcać zdecydowanie więcej miejsca w problematyce porządku politycznego i czyhających nań zagrożeń. To tutaj bowiem, w obrębie działań wspólnotowych, kierowanych przecież przez pewne struktury władzy, rodzą się wielkie idee i wiara w możliwość kreowania innego, lepszego świata. Z programem politycznym lub religijnym występują charyzmatyczni przywódcy, zarażając innych swoimi poglądami. Ugrupowania polityczne, partie, rząd podlegają takim samym prawom psychologii jak wszystkie grupy społeczne. Radykalizacja poglądów, wzrost negatywnych, wrogich emocji wobec obcych czy w końcu gotowość do działań ekstremistycznych i uczestnictwa $\mathrm{w}$ dehumanizacji $\mathrm{w}$ świetle przedstawionych tutaj badań psychologicznych wydają się niestety przynależeć do natury życia społecznego. Podobnie jak nie ma szans na wyeliminowanie konfliktów międzyludzkich, tak też nie ma możliwości skutecznego wyeliminowania zagrożeń, jakie niesie z sobą dynamika grupowa. Zagrożenie to istnieć będzie zawsze, należałoby raczej zadać pytanie o możliwość jak najwcześniejszego dostrzeżenia rodzących się zagrożeń, na długo przed ich gwałtowną i niekontrolowaną eskalacją, wtedy bowiem istnieje jeszcze realna szansa wyhamowania pewnych zjawisk. Świadomość podstawowych choćby mechanizmów wydaje się więc istotna. 
Pisałem wcześniej, że problem dehumanizacji nie musi przybierać form jedynie behawioralnych, ponieważ w pewnym sensie przynależy do natury funkcjonowania ludzkiego umysłu, próbującego poradzić sobie z zagrożeniem i wykorzystującego ewolucyjnie wykształtowane strategie poznawcze w postaci infrahumanizacji. Ale dehumanizacja występuje też $\mathrm{w}$ jeszcze innej formie - jako dehumanizacja i infrahumanizacja samego siebie, co w konsekwencji może także prowadzić do dehumanizacji innych ${ }^{68}$. Najlepszym tego dowodem jest zjawisko depersonalizacji podmiotu, który zespalając się z zaufaną grupą, może zatracić własną podmiotowość i poczucie etyczne, a w odpowiednich, sprzyjających warunkach „rozpłynie się" do tego stopnia, że będzie gotów posunąć się do najbardziej destrukcyjnych zachowań $^{69}$. Dehumanizacja samego siebie może zachodzić w skonfliktowanych rolach społecznych, jak pokazał to eksperyment symulowanego więzienia, w którym to właśnie strażnicy (zwyczajni studenci) dopuszczali się aktów sadyzmu, wyzbywając się najbardziej podstawowych odruchów ludzkich wobec więźniów. W końcu dehumanizacja może objawiać się zatraceniem wykształtowanych ewolucyjnie zdolności poznawczych, to jest zdolności do krytycznej oceny sytuacji i faktycznego zagrożenia dla ,ja" i innych, prowadząc do tragedii osobistej i tysięcy ludzi. Efektem tak rozumianej dehumanizacji jest niestety zazwyczaj destrukcja psychologiczna, społeczna, polityczna, kulturowa, a następnie cierpienie własne i innych.

Nie chodzi jednak tylko o świadomość opisanych tu problemów. Chodzi przede wszystkim o świadome i intencjonalne oddziaływanie na rzeczywistość społeczną, tak by tworzyć - sprzeczne z negatywnymi konsekwencjami działających sił psychologicznych — realia życia społecznego pozwalającego skuteczniej hamować rozwój destrukcji i wzajemnej dehumanizacji. To bowiem, w jakim kierunku pójdzie poddany procesom depersonalizacji, rolom i autorytetom obywatel, zależy w dużym stopniu ,od kontekstu sytuacyjnego zachęcającego do pozytywnego lub negatywnego postępowania"70. Niestety kreowanie właściwego kontekstu jest oddziaływaniem o charakterze długofalowym, wymagającym konsekwentnej polityki i skoordynowanych na kilku poziomach programów chociażby edukacyjnych i prawnych. Nie brzmi to zbyt optymistycznie i taka ingerencja w rzeczywistość kulturową zazwyczaj nie budzi entuzjazmu. Sądzę jednak, że prędzej czy później nasilające się zjawiska publicznie akceptowanej agresji i uczestnictwa w odczłowieczaniu stosunków międzyludzkich zmuszą rządzących do podjęcia pewnych działań. Jednym z podstawowych postulatów podnoszonych przez większość psychologów jest nie tylko edukacja tolerancji i dialogu z odmiennością, ale też położenie szczególnego nacisku na rozwój przeróżnych form empatii i zdolności jej okazywania i to już w programach edukacji

68 M. Kouchaki et al., The link between self-dehumanization and immoral behavior, „Psychological Science" 29, 2018, nr 8, s. 1234-1246.

69 Chcę tu podkreślić, że nie utożsamiam depersonalizacji ja z samodehumanizacją, jednak zauważam, że pierwsze może prowadzić do drugiego.

70 E. Aronson, T. Wilson, R. Akert, Psychologia społeczna. Serce i umyst..., s. 370. 
młodzieży. W obecnych warunkach wydaje się to odległe, a nawet mało realne. Widoczna dość powszechnie tolerancja — płynącej nawet z najwyższych szczebli — nienawiści, rozbudzanie postaw konformistycznych, bezkrytyczna gloryfikacja władzy z wyraźnym wskazywaniem wrogów czy upraszczanie rzeczywistości dwubiegunową ideologią prawdy-fałszu lub swoich i obcych prowadzi nie tylko do zubożenia życia społecznego, kulturalnego i politycznego, lecz w prostej linii także do jego destabilizacji. Co więcej, wyzwala w dużych grupach pokłady bardziej prymitywnych dążeń i oczekiwań, co z kolei staje się podstawą programów politycznych partii zarówno rządzących, jak i ubiegających się o władzę na następne lata. Takie, powiedziałbym, żonglowanie na karuzeli dynamiki grupowej i na dążeniu ludzkiego umysłu do upraszczania sobie świata jest tyleż nieodpowiedzialne, ile niebezpieczne.

The way we treat others not only has implications for how human they see themselves, but also for how human we see ourselves [...]. Our humanity may be less attached to our own individual identities and more a product of our interactions with others. Those interactions may elevate our humanity, but when destructive, they become important sources of dehumanization ${ }^{71}$.

\section{Bibliografia}

Adorno Th., Osobowość autorytarna, Warszawa 2010.

Adorno Th., Frenkel-Brunswik E., Levinson D., Sanford N., The Authoritarian Personality, New York 1950.

Altemeyer B., Enemies of Freedom: Understanding Right-Wing Authoritarianism, San Francisco 1988.

Arendt H., Eichmann w Jerozolimie. Rzecz o banalności zła, Warszawa 2010.

Aronson E., Wilson T., Akert R., Psychologia społeczna, Poznań 2006.

Aronson E., Wilson T., Akert R., Psychologia społeczna. Serce i umyst, Poznań 1997.

Asch S., Effects of group pressure upon the modification of distortion of judgement, [w:] Group, Leadership and Men, red. W. Guetzkov, Pittsburg 1951, s. 76-92.

Asch S., Opinions and social pressure, „Scientific American” 1955, nr 193, s. 31-55.

Badie D., Groupthink, Iraq, and the war on terror: Explaining US policy shift toward Iraq, „Foreign Policy Analysis" 6, 2010, nr 4, s. 277-296.

Bandura A., Underwood B., Fromson M., Disinhibition of aggression through diffusion of responsibility and dehumanization of victims, ,Journal of Research in Personality” 1975, nr 9, s. 253-269.

Bar-Tal D., Raviv A., Spitzer A., The need and ability to achieve cognitive structuring: Individual differences that moderate the effect of stress on information processing, ,Journal of Personality and Social Psychology" 1999, nr 77, s. 31-51.

Bell M., First century groupthink: An exegetical case study, ,Journal of Biblical Integration in Business" 19,2016 , nr 1, s. 26-37.

Biddle B., Role Theory: Expectancies, Identities, and Behavior, New York 1979.

71 B. Brock, D. Crimston, Self-dehumanization, „Testing, Psychometrics, Methodology in Applied Psychology" 21, 2014, nr 3, s. 249.

Studia nad Autorytaryzmem i Totalitaryzmem 41, nr 4, 2019

(C) for this edition by CNS 
Blass T., Understanding behavior in the Milgram obedience experiment: The role of personality, situations, and their interactions, ,Journal of Personality and Social Psychology” 1991, nr 60, s. 398-413.

Bosak J., Sczesny S., Eagly A., The impact of social roles on trait judgments: A critical re-examination, „Personality and Social Psychology Bulletin” 2012, nr 38, s. 429-440.

Brock B., Crimston D., Self-dehumanization, „Testing, Psychometrics, Methodology in Applied Psychology" 21, 2014, nr 3, s. 241-250.

Brown R., Prejudice. Its Social Psychology, Oxford 1995.

Bruce S., Fundamentalizm, Warszawa 2006.

Burger J., Replicating Milgram. Would people still obey today?, „American Psychologist” 64, 2009, nr 1, s. 1-11.

Calissendorff L., Brosché J., Sundberg R., Dehumanization amidst Massacres: An examination of Dinka-Nuer intergroup attitudes in south Sudan, „Peace and Conflict: Journal of Peace Psychology" 25, 2019, nr 1, s. 37-48.

Citlak A., Dehumanizacja - patologia czy permanentny stan ludzkiego umystu? Spojrzenie z perspektywy psychologii poznania społecznego, „Studia nad Autorytaryzmem i Totalitaryzmem” 37, 2015, nr 1, s. 13-34.

Citlak A., Psychologiczne i językowe uprzedmiotowienie obcych (stereotypizacja i dehumanizacja wrogów), „Studia nad Autorytaryzmem i Totalitaryzmem” 40, 2018, nr 4, s. 7-30.

Doliński D., Grzyb T., Postuszni do bólu. O uległości wobec autorytetu 50 lat po eksperymencie Milgrama, Sopot 2017.

Duckitt J., Authoritarianism and group identification: A new view of an old construct, „Political Psychology" 1989, nr 10, s. 63-84.

Eagly A., Wood W., Social role theory, [w:] Handbook of Theories in Social Psychology, red. P. van Lange, A. Kruglanski, E. Higgins, Thousand Oks 2012, s. 458-476.

Ellemers N., Spears R., Doosje B., Self and social identity, „Annual Review of Psychology” 2002, nr 53, s. 161-186.

Esser J., Lindoeffer J., Groupthink and the space shuttle Challenger accident: Toward a quantitative case analysis, „Journal of Behavioral Decision Making” 1989, nr 2-3, s. 167-177.

Falomir-Pichastor J., Mugny G., Threatening intergroup relationships personal versus group-related moderators of conformity as a function of the level of self-categorization, „Social Psychology" 2, 2011, nr 4, s. 279-291.

Das Faschismus Syndrom: Zur Psychoanalyse der Neuen Rechten in Europa, red. E. Modena, Giessen 1998.

Freund T., Kruglanski A., Schpitzajzen T., The freezing and unfreezing of impressional primacy: Effects of the need for structure and fear of invalidity, „Personality and Social Psychology Bulletin" 1985, nr 11, s. 479-487.

Fromm E., Anatomia ludzkiej destrukcyjności, Poznań 2014.

Fromm E., Arbeiter und Angestelte am Vorabend des Dritten Reiches. Eine sozialpsychologische Untersuchung, [w:] Erich Fromm: Gesamtausgabe, t. 3. Empirische Untersuchungen zum Gessellschafts-Charakter, red. R. Funk, München 1989, s. 1-230.

Fromm E., Psychoanalytische Charakterologie in Theorie und Praxis. Der Gessellschafts-Charakter eines mexikanischen Dorfes, [w:] Erich Fromm: Gesamtausgabe, t. 3. Empirische Untersuchungen zum Gessellschafts-Charakter, red. R. Funk, München 1989, s. 231-540.

Fromm E. Sozialpsychologischer Teil, [w:] Studien über Autorität und Familie. Schriften des Instituts für Sozialforschung, t. 5, red. M. Horkheimer, Paris 1936, s. 77-135.

Fromm E., Ucieczka od wolności, Warszawa 1998.

Gilbert S., Another look at the Milgram obedience studies: The role of the graduated series of shocks, „Personality and Social Psychology Bulletin” 1981, nr 7, s. 690-695. 
Golec de Zavala A., Cisłak A., Wesołowska E., Political conservatism, need for cognitive closure, and intergroup hostility, „Political Psychology” 31, 2010, nr 4, s. 521-541.

Goldhill S., Wielkie Dionizja a ideologia obywatelska, [w:] Antropologia antyku greckiego, oprac. W. Lengauer, L. Trzcionkowski, red. W. Lengauer, P. Majewski, L. Trzcionkowski, Warszawa 2011, s. 453-476.

Griffin J., Społeczna funkcja tragedii attyckiej, [w:] Antropologia antyku greckiego, oprac. W. Lengauer, L. Trzcionkowski, red. W. Lengauer, P. Majewski, L. Trzcionkowski, Warszawa 2011, s. $477-502$.

Haney C., Banks C., Zimbardo Ph., Więźniowie i strażnicy — badanie w symulowanym więzieniu, [w:] Człowiek istota społeczna. Wybór tekstów, red. E. Aronson, Warszawa 2002, s. 83-101.

Hällgren M., Groupthink in temporary organizations, „International Journal of Managing Projects in Business" 3, 2010, nr 1, s. 94-109.

Herrera C., Ethics, deception, and ,those Milgram experiments”, „Journal of Applied Philosophy” 2001, nr 18, s. 245-256.

Hornsey M., Social identity theory and self-categorization theory: A historical review, „Social and Personality Psychology Compass" 2008, nr 2, s. 204-222.

Huynh Q., Devos T., Altman H., Boundaries of American identity: Relations between ethnic group, prototypicality and policy attitudes, „Political Psychology” 2015, nr 36, s. 449-468.

Iacoviello V., Lorenzi-Cioldi F., Self-depersonalization and ingroup favoritism in minimal group hierarchies, „Swiss Journal of Psychology” 77, 2018, nr 1, s. 5-14.

Jakubowska U., O naturze preferencji politycznych. Perspektywa psychologiczna, Warszawa 2018.

Jakubowska U., Preferencje polityczne. Psychologiczne teorie i badania, Warszawa 1999.

Jakubowska U., Oniszczenko W., The role of personality, cognitive, environmental and genetic factors as determinants of religious fundamentalism: A twin study in a Polish sample, „Studia Psychologica" 2010, nr 52, s. 253-263.

Janis I., Groupthink: Psychological Studies of Policy Decisions and Fascoes, Boston 1982.

Janis I., Victims of Groupthink, Boston 1972.

Jost T., Kruglanski A., Glaser J., Sulloway F., Political conservatism as motivated social cognition, „Psychological Bulletin” 2003, nr 29, s. 339-375.

Korzeniowski K., Autorytaryzm i jego psychopolityczne konsekwencje, [w:] Podstawy psychologii politycznej, red. K. Skarżyńska, Poznań 2002, s. 59-81.

Kossowska M., Nowe poznawcze wymiary osobowości a spoleczne poznanie i działanie, [w:] Psychologia poznania społecznego, red. M. Kofta, M. Kossowska, Warszawa 2009, s. 236-237.

Kossowska M., Umyst niezmienny. Poznawcze mechanizmy sztywności, Kraków 2005.

Kouchaki M., Dobson K., Waytz A., Kteily N., The link between self-dehumanization and immoral behavior, „Psychological Science” 29, 2018, nr 8, s. 1234-1246.

Kruglanski A., Freund T., The freezing and unfreezing of lay inferences: Effects on impressional primacy, ethnic stereotyping, and numerical anchoring, „Journal of Experimental Social Psychology" 1983, nr 19, s. 448-468.

Kruglanski A., Klar Y., Widok z mostu: integrowanie paradygmatów teorii zgodności i teorii atrybucji z perspektywy epistemologii naiwnej, [w:] Poznanie, afekt, zachowanie, red. T. Maruszewski, Warszawa 1993, s. 216-258.

Kruglanski A., Webster D., Motivated closing of the mind: „, Seizing” and ,freezing”, „Psychological Review" 1996, nr 103, s. 263-283.

Kteily N., Bruneau E., Darker demons of our nature: The need to (re)focus attention on blatant forms of dehumanization, „Current Directions in Psychological Science” 26, 2017, nr 6, s. 487-494.

Langer E., Benevento A., Self-induced dependence, „Journal of Personality and Social Psychology” 1978, nr 36, s. 886-893.

Latane B., Nowak A., Liu J., Measuring emergent social phenomena: Dynamism, polarisation and clustering as order parameters of social systems, „Behavioral Science” 1994, nr 39, s. 1-24.

Studia nad Autorytaryzmem i Totalitaryzmem 41, nr 4, 2019

(C) for this edition by CNS 
LeBon G., Psychologia ttumu, Warszawa 1986.

Lewin K., Dynamic Theory of Personality, New York 1936.

Lewin K., Frontiers in group dynamics, „Human Relations” 1, 1947, nr 2, s. 5-41.

Lewin K., Resolving Social Conflicts and Field Theory in Social Science, Washington 1997.

Lindén M., Björklund F., Bäckström M., What makes authoritarian and socially dominant people more positive to using torture in the war on terrorism?, „Personality and Individual Differences" 2016, nr 91, s. 98-101.

McDougall W., The Group Mind, London 1921.

McWiliams N., Diagnoza psychoanalityczna, Gdańsk 2008.

Meeus W., Raaijmakers Q., Administrative obedience: Carrying out orders to use psychological-administrative violence, „European Journal of Social Psychology” 1986, nr 16, s. 311-324.

Messe L., Kerr N., Sattler D., „But same animals are more equals than others”. The supervisor as a privileged status in group contexts, [w:] Group Processes and Productivity, red. S. Worchel, W. Wood, J. Simpson, Newbury Park 1992, s. 203-223.

Meyers D., Psychologia społeczna, Poznań 2003.

Milgram S., Behavioral study of obedience, „Journal of Abnormal and Social Psychology” 1963, nr 67, s. 371-378.

Milgram S., Obedience to Authority: An Experimental View, New York 1974.

Milgram S., Postuszeństwo wobec autorytetu. Eksperyment, który wystawit na próbę ludzką naturę, Sopot 2017.

Miller A., Postuszeństwo, [w:] Psychologia społeczna. Encyklopedia Blackwella, red. A. Manstaed, M. Hewstone, Warszawa 2001, s. 389-395.

Miller A., What can the Milgram obedience experiments tell us about the Holocaust? Generalizing from the social psychology laboratory, [w:] The Social Psychology of Good and Evil, red. A. Miller, New York 2004, s. 193-239.

Miller A., Zniewolone dzieciństwo. Ukryte źródta tyranii, Poznań 2013.

Mintz A., Schneidermann I., From groupthink to polythink in the Yom Kippur war decisions of 1973, „European Review of International Studies” 5, 2018, nr 1, s. 48-66.

Moscovici S., Three concepts: Minority, conflict and behavioral style, [w:] Minority Influence, red. W. Moscovici, A. Mucchi-Faina, A. Maass, Chicago 1994, s. 233-251.

Motyl M., Hart J., Pyszczynski T., When animals attack: The effects of mortality salience, infrahumanization of violence, and authoritarianism on support for war, ,Journal of Experimental Social Psychology" 46, 2010, nr 1, s. 200-203.

Neuberg S., Newsom J., Personal need for structure: Individual differences in the desire for simple structure, ,Journal of Personality and Social Psychology” 1993, nr 65, s. 113-131.

Nowak A., Szemrej J., Latane B., From private attitude to public opinion, „Psychological Review” 1990, nr 97, s. 362-376.

Packer D., Avoiding groupthink: Whereas weakly identified members remain silent, strongly identified members dissent about collective problems, „Psychological Science” 20, 2009, nr 5, s. 546-548.

Prati F., Moscatelli S., Prato F., Rubini M., Predicting support for Arabs' autonomy from social dominance: The role of identity complexity and dehumanization, „Political Psychology” 37, 2016, nr 2, s. 293-301.

Radkiewicz P., Autorytaryzm a brzytwa Okhama, Warszawa 2012.

Rączaszek-Leonardi J., Symbols as constraints: The structuring role of dynamics and self-organization in natural language, „Pragmatics and Cognition” 17, 2009, nr 3, s. 653-676.

Richter H., Zur Psychoanalyse der Rechtsradikalismus, [w:] Das Faschismus Syndrom: Zur Psychoanalyse der Neuen Rechten in Europa, red. E. Modena, Giessen 1998, s. 228-239.

Roets A., VanHiel A., Separating ability from need: Clarifying the dimensional structure of the need for closure scale, „Personality and Social Psychology Bulletin” 2007, nr 33, s. 266-280.

Studia nad Autorytaryzmem i Totalitaryzmem 41, nr 4, 2019

(C) for this edition by CNS 
Rokeach M., McGovney W., Denny R., Dogmatic thinking versus rigid thinking. An experimental distinction, [w:] The Open and Closed Mind. Investigations into the Nature of Belief Systems and Personality Systems, red. M. Rokeach, New York 1960, s. 182-195.

Ross M., The relevance of culture for the study of political psychology and ethnic conflict, „Political Psychology" 1997, nr 18, s. 299-326.

Shah J., Kruglanski A., Thompson E., Membership has its (epistemic) rewards: Need for closure effects on in-group bias, ,Journal of Personality and Social Psychology” 1998, nr 75, s. 383-393.

Seligman M., Walker E., Rosenhan D., Psychopatologia, Warszawa 2003.

Sidanius J., Prato F., Social Dominance: An Intergroup Theory of Social Hierarchy and Oppresion, New York 1999.

Sidanius J., Prato F., vanLaar C., Levin S., Social dominance theory: Its agenda and method, „Political Psychology" 25, 2004, nr 6, s. 854-880.

Suedfeld P., Schaller M., Autorytaryzm i Holokaust. Wybrane implikacje poznawcze i afektywne, [w:] Zrozumieć zagładę. Społeczna psychologia Holokaustu, red. L. Newman, R. Erber, Warszawa 2009, s. 65-84.

Suedfeld P., Tetlock Ph., Ingrative complexity at forty: Steps toward resolving the scoring dilemma, „Political Psychology” 2014, nr 35, s. 597-602.

Środa M., Indywidualizm i jego krytycy: wspótczesne spory między liberałami, komunitarianami i feministkami na temat podmiotu, wspólnoty i ptci, Warszawa 2009.

Tetlock Ph., Cognitive structural analysis of political rhetoric: Methodological and theoretical issues, [w:] Explorations in Political Psychology, red. S. Iyengar, W. McGuire, London 1993, s. $380-406$.

Trounson J., Critchley Ch., Pfeifer J., Australian attitudes toward asylum seekers: Roles of dehumanization and social dominance theory, „Social Behavior and Personality” 2015, $\mathrm{nr} 43$, s. 1641-1656.

Turner J., Social categorization and the self-concept: A social cognitive theory of group behaviour, [w:] Advances in Group Processes, t. 2. Theory and Research, red. E. Lawler, Greenwich 1985, s. $77-122$.

Turner J., Hogg A., Oakes J., Reicher S., Wethrell M., Rediscovering the Social Group: A Self-Categorization Theory, Oxford 1987.

Turner J., Oakes P., Haslam S., McGarty C., Self and collective: Cognition and social context, „Personality and Social Psychology Bulletin" 1994, nr 20, s. 454-463.

Turner M., Pratkanis A., A social identity maintenance model of groupthink, „Behavior and Human Decision Processes" 73, 1998, nr 2-3, s. 210-235.

Turner R., Role-taking: Proces vs conformity, [w:] Human Behavior and Social Process, red. A. Rose, Boston 1962, s. 20-40.

Tyszka T., Psychologiczne pułapki oceniania i podejmowania decyzji, Gdańsk 2000.

Verkuyten M., Hagendoorn L., Prejudice and self-categorization: The variable role of authoritarianism and ingroup stereotypes, „Personality and Social Psychology Bulletin” 1998, nr 24, s. $99-110$.

Webster D., Kruglanski A., Pattison D., Motivated language use in intergroup contexts, „Journal of Personality and Social Psychology" 1997, nr 72, s. 1122-1231.

Witwicki W., Psychologia, t. 2, Warszawa 1963.

Witwicki W., Z psychologii stosunków osobistych, „Przegląd Filozoficzny” 1907, nr 10, s. 531-537.

Wojciszke B., Doliński D., Psychologia społeczna, [w:] Psychologia akademicka, t. 2, red. J. Strelau, D. Doliński, Gdańsk 2010, s. 292-447.

Wood W., Lundgren S., Ouellette J., Busceme S., Blackstone T., Minority influence: A meta-analytic of social influence processes, „Psychological Bulletin” 1994, nr 115, s. 323-345.

Zimbardo Ph., Efekt Lucyfera. Dlaczego dobrzy ludzie czynia zło?, Warszawa 2008.

Studia nad Autorytaryzmem i Totalitaryzmem 41, nr 4, 2019

(C) for this edition by CNS 


\section{THE PSYCHOLOGICAL DETERMINANTS OF ACTS OF DEHUMANIZATION}

\section{Summary}

The article discusses the most important sources of various forms of dehumanization and destructive behavior. Modern knowledge and psychological research allow to understand dehumanization as a phenomenon going beyond behavioral acts. The main goal of this article is the presentation of two psychological traditions, that explain violence and social aggression in the light of the individual's mental dysfunctions, as well as in the light of the dynamics of social processes (above all group processes and interpersonal interaction). Presentation of this second research tradition is in my opinion of key importance for understanding the most important and the most serious determinants of dehumanization, although it is systematically underestimated or little known in sociological and political science literature. Identification of relevant sources of dehumanization can contribute to their quicker identification and inhibition.

Keywords: social determinants of destruction, pathology, dehumanization, infra-humanization, self-dehumanization.

Amadeusz Citlak

acitlak@wp.pl, acitlak@psych.pan.pl 